\title{
The Effect of Partially Substituted Lupin, Soybean, and Navy Bean Flours on Wheat Bread Quality
}

\author{
Sean Liu, Diejun Chen, Jingyuan Xu \\ National Center for Agricultural Utilization Research, Agricultural Research Service, US Department of Agriculture, \\ Peoria, IL, USA \\ Email: sean.liu@ars.usda.gov
}

How to cite this paper: Liu, S., Chen, D. and Xu, J.Y. (2018) The Effect of Partially Substituted Lupin, Soybean, and Navy Bean Flours on Wheat Bread Quality. Food and Nutrition Sciences, 9, 840-854. https://doi.org/10.4236/fns.2018.97063

Received: June 19, 2018

Accepted: July 16, 2018

Published: July 19, 2018

Copyright ( 92018 by authors and Scientific Research Publishing Inc. This work is licensed under the Creative Commons Attribution International License (CC BY 4.0).

http://creativecommons.org/licenses/by/4.0/

\section{(c) (i) Open Access}

\begin{abstract}
Many edible legumes contain high amounts of proteins, fibers, minerals and vitamins. Their essential amino acid composition and concentration complements the amino acids in wheat and other cereals. In addition, breads fortified with protein rich legumes make the breads more palatable. In this study, we evaluated breads made from wheat flour partially substituted with soybean, navy bean, and lupin flours at $10 \%, 20 \%$, and $30 \%$ levels. The physicochemical properties of breads were measured and compared with the control (made from $100 \%$ wheat flour). Statistical analysis was used to assess the significance of the differences. The breads fortified with soybean, lupin and navy bean flours showed remarkable springiness, similar to the breads made from wheat flour. However, the higher amount of substitution increased the firmness of the breads, probably due to the incorporation of additional fibers and proteins into the formulations. Compared to wheat bread, the volumes of 90:10 wheatsoybean, wheat-lupin, and wheat-navy bean breads decreased about $7 \%, 2 \%$, and $10 \%$, respectively. Higher substitution levels would result in a higher reduction in volume for all legumes tested. The volume reduction as a result of legume substitution appears to be navy bean flour > soybean flour > lupin flour. The inclusion of legumes in the bread formulations imparts a slightly darker crust color and crumb color with the exception of breads with the soybean flour substitution. Lupin appears to be the best substitution candidate among the legumes tested for fortified bread making. Lupin can be presented as a high-value protein source in developing marketable foods for health conscious consumers.
\end{abstract}

\section{Keywords}

Bread Quality, Lupin, Navy Bean, Rheology, Soybean, Wheat 


\section{Introduction}

Recently, more health-conscious consumers are eagerly searching for plant-based protein-rich food products for weight management, cancer prevention, and cardiovascular health. Legumes, including lupin (Lupinus angustifolius L.), soybean and navy bean, are important crops in the world because of their unique nutritional quality.

Lupin seeds have been used in human food and animal feed since ancient times. It is well known that the antioxidant phytochemicals in lupin have many health benefits including prevention of various diseases associated with oxidative stress such as cancer, cardiovascular disease, neuro-degeneration and diabetes [1]. Furthermore, lupin grains are rich sources of complex carbohydrates, protein, dietary fiber, vitamins and minerals [2].

Soybean has been used as a food source of high-quality protein and other nutrients for hundreds of years. The seed is rich in several compounds of biological interest, such as phytosterols, saponins, protease inhibitors and isoflavones [3]. During last decade, there has been increasing interest in isoflavones due to their potential health benefits, including the prevention of certain types of cancer, cardiovascular diseases, osteoporosis and alleviation of menopausal symptoms [4].

Navy beans are recognized as an excellent source of minerals, including calcium, iron, phosphorus, potassium, zinc, as well as dietary fiber (15.3\%), and twice the amount of protein (22.3\%) than cereals [2]. In addition, navy beans are known to have a large amount of vitamins as well as a low Glycemic Index. Beans in the diet significantly reduce cholesterol levels [5]. Dietary fiber can provide protection from serious health concerns such as heart disease, diabetes, obesity, colon cancer, and diverticulitis [6]. Evidence also suggests that the bioactive compounds in pulses help reduce the risk of certain cancers, diabetes, and heart disease [7] [8].

Currently, consumer requests for plant protein enriched bakery products are being addressed due to health concerns. A variety of lupin, soybean, and navy bean products have been brought into the market to meet this need. However, lupin products are still not common in the marketplace despite the scientific facts. Although there are many recipes using lupin, soybean, and navy bean, they were not scientifically compared and reported. Besides the nutritional benefits, protein rich legumes would make the breads more attractive (palatable). In this study, we investigated bread qualities partially substituted with soybean, navy bean, and lupin flours at 10\%, 20\%, and $30 \%$ of substitution levels, and compared the properties of three kinds of partially substituted breads with wheat flour bread.

\section{Materials and Methods}

\subsection{Ingredient}

All-purpose wheat flour (Hy-Vee, Inc., West Des Moines, IA, USA); lupin flour 
(Lupina, LLC., Mount Shasta, CA, USA); whole navy bean flour (Mrs. Glee's Gluten Free Foods Company, Hillman, MI, USA); whole soy flour (Bob's Red Mill Natural Foods, Inc., Milwaukie, OR, USA); sugar (C\&H Sugar Company, Crockett, CA, USA); nonfat dry milk (Carnation, Nestlé, Vevey Switzerland), Crisco shortening (Crisco, the J.M. Smucker Company, Orrville, OH, USA); egg white powder (Deb-El Food Products, Elizabeth, NJ, USA); and SAF-INSTANT yeast (Lesaffre Yeast Corporation, Milwaukee, WI, USA).

\subsection{Bread Preparation}

Bread formulas and procedures were developed based on the modified AACC method 10-09 [9]. In this work, $100 \%$ all-purpose wheat flour bread was used as a control. In nine other samples, wheat flour was replaced by lupin, soybean, and navy bean flour at $10 \mathrm{wt} . \%, 20 \mathrm{wt} \%$, and $30 \mathrm{wt} . \%$, respectively. Each batch of dough contained flour (200 g), sugar (12 g), salt ( $3 \mathrm{~g})$, milk powder (4 g), egg white powder $(4 \mathrm{~g})$, and shortening $(6 \mathrm{~g})$, instant yeast $(4 \mathrm{~g})$, and water $(120 \mathrm{~g}$, $\left.31^{\circ} \mathrm{C}\right)$.

Dry yeast was added to a container and reconstituted in warm water. The dry ingredients were mixed with a wire whip in a bowl using a KitchenAid electric mixer (Whirlpool Corporation, Benton Harbor, MI, USA) at low speed for 1 min. The wire whip was changed to a dough hook blade and the reconstituted yeast was added gradually into the flour mixture in the mixing bowl; this was mixed for 2 min at low speed. The bowl was scraped down and mixing continued at low speed until the dough formed a ball that separated cleanly from the side of the bowl. The dough was weighed and divided into two portions; each one was placed on a lightly floured surface and shaped into a ball. The dough was placed into lightly greased metal loaf baking pans $(13.6 \times 7.0 \mathrm{~cm}$ top inside; $12.0 \times 5.1 \mathrm{~cm}$ bottom outside; $5.0 \mathrm{~cm}$ inside depth) with the folded edges of the dough at the bottom. The dough was covered with a moist cloth and allowed to rise (proofing) at $31^{\circ} \mathrm{C}$. When the dough doubled in size, it was rolled evenly into a rectangle in a jelly-roll fashion, and the ends of the dough were pinched with fingers to seal the loaf well. The shaped loaf was returned to the bread pan with the seam side down. The loaf was allowed to rise (proofing) uncovered in the incubator until the top of the loaf rose $1 \mathrm{~cm}$ above the bread pan. The loaf was baked at $350^{\circ} \mathrm{F}$ in an oven (UNOX, Padova, Italy) for $20 \mathrm{~min}$. The loaf was removed from the pan immediately after removal from the oven, cooled for $1 \mathrm{~h}$ on a wire rack, and then stored in polyethylene bags at room temperature $\left(24^{\circ} \mathrm{C}\right)$ for further testing.

\subsection{Water Holding Capacity}

The water holding capacity (WHC) of the samples was determined by a previous procedure with minor modifications [10]. Each sample (2 g, dry weight) was mixed with $25 \mathrm{~g}$ of distilled water and vigorously mixed for $1 \mathrm{~min}$ to a homogenous suspension using a Vortex stirrer, held for $2 \mathrm{~h}$, and centrifuged at $1590 \mathrm{~g}$ 
for $10 \mathrm{~min}$. Each treatment was replicated twice. The WHC was calculated by the difference between the weight of water added and decanted on a dry basis ( $g$ of water absorbed/100 $\mathrm{g}$ of dry sample).

\subsection{Water Loss and Moisture Content}

The water losses during baking were calculated by the weight differences before and after baking. The moisture content was determined by drying the samples at $105^{\circ} \mathrm{C}$ to a constant weight.

\subsection{Bread volume, Specific Volume, and $\mathrm{pH}$}

Bread volume was determined by rapeseed displacement according to AACC method 10-05.01 [11]. The specific loaf volumes were obtained by dividing the volume by the loaf weight (expressed as $\mathrm{mL} / \mathrm{g}$ ).

For $\mathrm{pH}, 10 \mathrm{~g}$ of bread crumbs were homogenized with $90 \mathrm{~mL}$ of distilled water in a blender using a previous method [12]. The $\mathrm{pH}$ value was measured and recorded using a pH electrode (Thermo Fisher Scientific, Beverly, MA USA).

\subsection{Rheological Measurements of Formulated Suspensions}

The suspensions with $10 \mathrm{wt} . \%$ solid content were made using wheat flour and nine wheat flour blends with lupin, soybean, and navy bean at $10 \%, 20 \%$, and $30 \%$, respectively. Each suspension was placed in a bottle covered by a watching glass, and heated at $90^{\circ} \mathrm{C}$ in a water bath for 30 min while stirring by a glass rod. The heated samples were capped, allowed to cool down to $25^{\circ} \mathrm{C}$, equilibrated overnight, and loaded on a stress-controlled rheometer (AR 2000, TA Instruments, New Castle, DE, USA) using a $6 \mathrm{~cm}$ diameter parallel acrylic plate geometry with $1 \mathrm{~mm}$ gap. The chamber was kept at $25^{\circ} \mathrm{C} \pm 0.1^{\circ} \mathrm{C}$ by a water circulation system. In order to keep the chamber moist, the edge of the plate was sealed with mineral oil (Sigma Chemical Co., St Louis, MO, USA). A strain sweep experiment was initially conducted to identify the linear range of the viscoelasticity. An applied strain valued in the linear range was adopted for the other linear viscoelastic property measurements for the same material; fresh samples were used for each experiment. The linear viscoelasticity indicates that the measured moduli are independent of applied shear strain. Dynamic small-amplitude oscillatory experiments were conducted over a frequency $(\omega)$ range of $0.1-500 \mathrm{rad} / \mathrm{s}$ within linear strain, yielding the shear storage or elastic $\left(G^{\prime}\right)$ and loss or viscous (G') moduli. The storage or elastic modulus (G') represents the non-dissipative component of the mechanical properties. The elastic or "rubber-like" behavior is suggested if the G' spectrum is independent of frequency and greater than the loss modulus over a certain range of frequency. The loss or viscous modulus (G") represents the dissipative component of the mechanical properties and is characteristic of viscous flow. The loss tangent, $\tan (\delta)=\mathrm{G}^{\prime \prime} / \mathrm{G}^{\prime}$, in which $\delta$ is called phase shift or phase angle, was often used to indicate whether a material is solid with perfect elasticity $(\tan (\delta)=0)$, or liquid with pure viscosity $(\tan (\delta)=$ 
$\infty)$, or viscoelasticity $(0<\tan (\delta)<\infty)$. The loss tangent greater than one $(\tan (\delta)>1)$ suggests that the material exhibits more viscous-like viscoelastic behavior, while the loss tangent lower than one $(\tan (\delta)<1)$ suggests that the material exhibits more solid-like viscoelastic properties [13]. The non-linear rheological measurements were carried out by steady shear experiments. The viscosities of the sample suspensions were measured with shear rates from 1 to $100 \mathrm{~s}^{-1}$.

\subsection{Bread Resilience and Firmness}

Bread resilience and firmness was measured using a TA-XT2 Texture Analyzer (Texture Technology Corporation, Scarsdale, NY, USA) modified by a $35 \mathrm{~mm}$ cylinder probe with a $5 \mathrm{~kg}$ loading cell on sliced bread $(25 \mathrm{~mm})$. The force at $25 \%$ compression at $1.7 \mathrm{~mm} / \mathrm{s}$ is the firmness value. After the probe continued to compress the sample to $60 \%$ of the original sample height ( $40 \%$ strain), the probe held this position for $2 \mathrm{sec}$. Next, the probe withdraws and waits $15 \mathrm{sec}$ to allow the sample to recover. The probe moves down slowly as it searches for the new position (post-test height) of the sample. The original height divided by the post-test height $\mathrm{X} 100$ gives the resilience in \%. The testing was performed in triplicate, and the force (firmness) was recorded in grams.

\subsection{Color}

The color parameters $\mathrm{L}^{*}, \mathrm{a}^{*}, \mathrm{~b}^{*}$ were determined by a Hunter Lab spectrocolorimeter (Labscan XE, Hunter Associates Laboratory Inc., Reston, VA, USA). The colorimeter was calibrated using standard black and white plate. Samples were measured in triplicate.

\subsection{Statistical Analysis}

The color parameters $\mathrm{L}^{*}, \mathrm{a}^{*}, \mathrm{~b}^{*}$ were determined by a Hunter Lab spectrocolorimeter (Labscan XE, Hunter Associates Laboratory Inc., Reston, VA, USA) [14]. The colorimeter was calibrated using standard black and white plate. Samples were measured in triplicate.

\section{Results and Discussions}

\subsection{Properties of the Ingredients}

Protein is one of the most important nutritional components for human beings. The lupin, soybean, and navy bean flours have high protein contents of $36.17 \%$, $36.49 \%$, and $22.33 \%$ respectively, which are all greater than wheat $(9.61 \%)$ (Table 1). Therefore, the addition of soybean, lupin and navy bean flour to bread will greatly improve the protein content in bread. Dietary fiber is well known for helping to maintain a healthy weight and lower the risk of diabetes and heart disease (McPherson, 1992). Among all flours that we used, lupin has the highest noticeable fiber content of $18.90 \%$, while the fiber contents of navy bean and soybean are $15.30 \%$, and $9.30 \%$ respectively [2] (USDA National Nutrient Database, 2017). Lipid content could affect food product texture and flavor. 
Table 1. The properties of staring ingredients.

\begin{tabular}{|c|c|c|c|c|c|c|c|c|c|c|}
\hline & Moisture & $\mathrm{WHC}^{1}$ & Protein $^{2}$ & $\operatorname{lipid}^{2}$ & Carbohydra & ${ }^{2}$ Fiber $^{2}$ & & Color & & Brown \\
\hline & $\%$ & $\%$ & $\%$ & $\%$ & $\%$ & $\%$ & $L^{3}$ & $a^{3}$ & $b^{3}$ & index \\
\hline wheat flour & $11.26^{\mathrm{a}}$ & $86.62^{\mathrm{d}}$ & $9.61^{c}$ & $1.95^{\mathrm{c}}$ & $74.48^{\mathrm{a}}$ & $13.10^{\mathrm{c}}$ & $91.07^{\mathrm{a}}$ & $0.79^{c}$ & $9.11^{\mathrm{d}}$ & $8.93^{c}$ \\
\hline soybean flour & $6.46^{\mathrm{b}}$ & $202.26^{\mathrm{b}}$ & $36.49^{\mathrm{a}}$ & $19.94^{\mathrm{a}}$ & $30.16^{\mathrm{d}}$ & $9.30^{\mathrm{d}}$ & $88.49^{c}$ & $0.90^{\mathrm{d}}$ & $25.17^{\mathrm{b}}$ & $11.50^{\mathrm{a}}$ \\
\hline Lupin flour & $6.03^{\mathrm{b}}$ & $155.17^{\mathrm{c}}$ & $36.17^{\mathrm{a}}$ & $9.74^{\mathrm{b}}$ & $40.37^{c}$ & $18.90^{\mathrm{a}}$ & $88.38^{c}$ & $1.22^{\mathrm{b}}$ & $27.53^{\mathrm{a}}$ & $11.62^{\mathrm{a}}$ \\
\hline Navy bean flour & $4.80^{\mathrm{c}}$ & $293.70^{\mathrm{a}}$ & $22.33^{\mathrm{b}}$ & $1.5^{\mathrm{d}}$ & $60.75^{\mathrm{b}}$ & $15.30^{\mathrm{b}}$ & $88.71^{\mathrm{b}}$ & $2.08^{\mathrm{a}}$ & $13.57^{\mathrm{c}}$ & $=11.29^{\mathrm{b}}$ \\
\hline
\end{tabular}

${ }^{1}$ water holding capacity. ${ }^{2}$ Data were selected form USDA nutrition data base. ${ }^{3}$ Color values by colorimeter. Means followed by the same letter within the same column are not significantly different $(P>0.05)$.

Soybean has the highest lipid content (19.94\%) among all flours tested, followed by lupin $(9.74 \%)$, wheat (1.95\%) and navy bean (1.5\%) (Table 1 ).

Water holding capacity (WHC) is an important property for food processing and quality. In addition, WHC is the ability of a protein matrix to absorb and retain bound, hydrodynamic, capillary and physically entrapped water against gravity in a previous report [15]. Navy bean, soy, and lupin flours possessed WHCs of $293.70 \%, 202.26 \% .155 .17 \%$ respectively, which were all higher than that of wheat flour (86.62\%). Apparently, greater protein compositions of navy bean, soy, and lupin at least partially contributed higher WHCs. Navy bean flour had the highest WHC credited to fairly high protein (22.33\%) and carbohydrate $(60.75 \%)$ content and their interactions. The high WHC may also be attributed to the loose fibril arrangement, more branched structure, larger pore size, and higher surface area per unit mass or higher hydrophilic nature [16]. The results above suggests that WHC is a complex of protein-carbohydrate-fiber-water interactions.

\subsection{Rheological Properties of Formulated Suspensions}

It is well known that the dynamic viscoelastic properties of the bread materials are related to their baking quality. The elastic (storage) modulus G' vs. frequency for wheat and wheat-soybean blend suspensions, for wheat and wheat-lupin blend suspensions, and for wheat and wheat-navy bean blend suspensions are shown in Figures 1(a)-(c) respectively. All measured suspensions had the $\tan (\delta)$ value $<1$ indicating solid-like viscoelastic behaviors (Figures $2(a)-(c)$ ). Wheat flour suspensions exhibited the highest G' values among all measured samples, which was expected because wheat flour had greatest amount of gluten. The storage modulus at $1 \mathrm{rad} / \mathrm{s}$ for wheat flour suspension was $131.4 \mathrm{~Pa}$. The interactions of the wheat gluten and starch made the wheat flour suspension exhibit highest elastic moduli (Figures 1(a)-(c)). Soybean, lupin, and navy bean have higher content of proteins than wheat (Table 1), but these proteins are gluten-free. All blend suspensions of soybean, lupin, and navy bean with wheat exhibited weaker viscoelastic behaviors than wheat alone. The storage modulus at $1 \mathrm{rad} / \mathrm{s}$ for the 90:10, 80:20, and 70:30 blends of wheat-soybean suspensions were $39.05 \mathrm{~Pa}$, $28.89 \mathrm{~Pa}$ and $25.63 \mathrm{~Pa}$, respectively (Figure $1(\mathrm{a})$ ). The storage modulus at $1 \mathrm{rad} / \mathrm{s}$ 

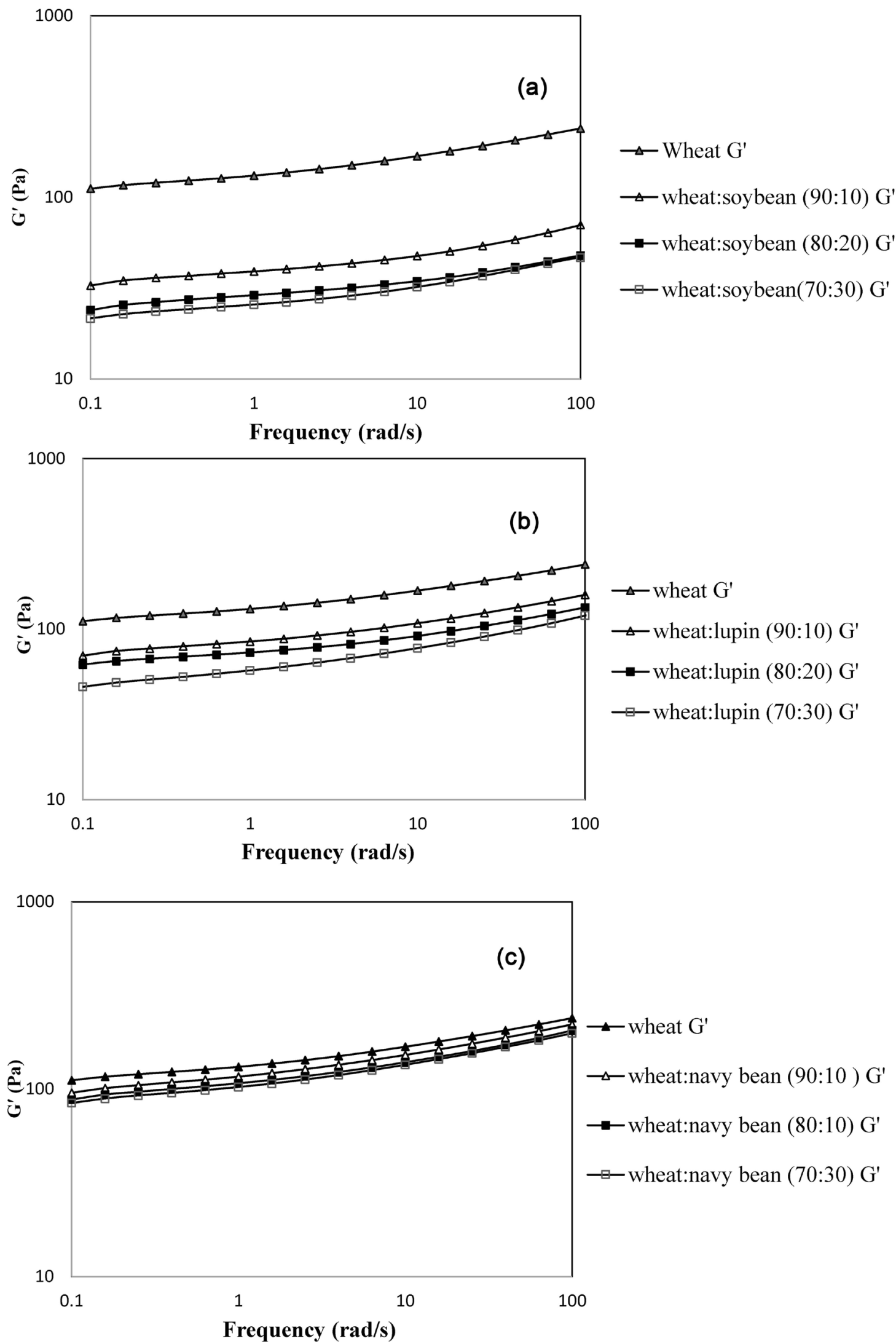

Figure 1. Dynamic viscoelastic properties for suspensions of wheat and its blends with soybean, lupin and navy bean flours. 


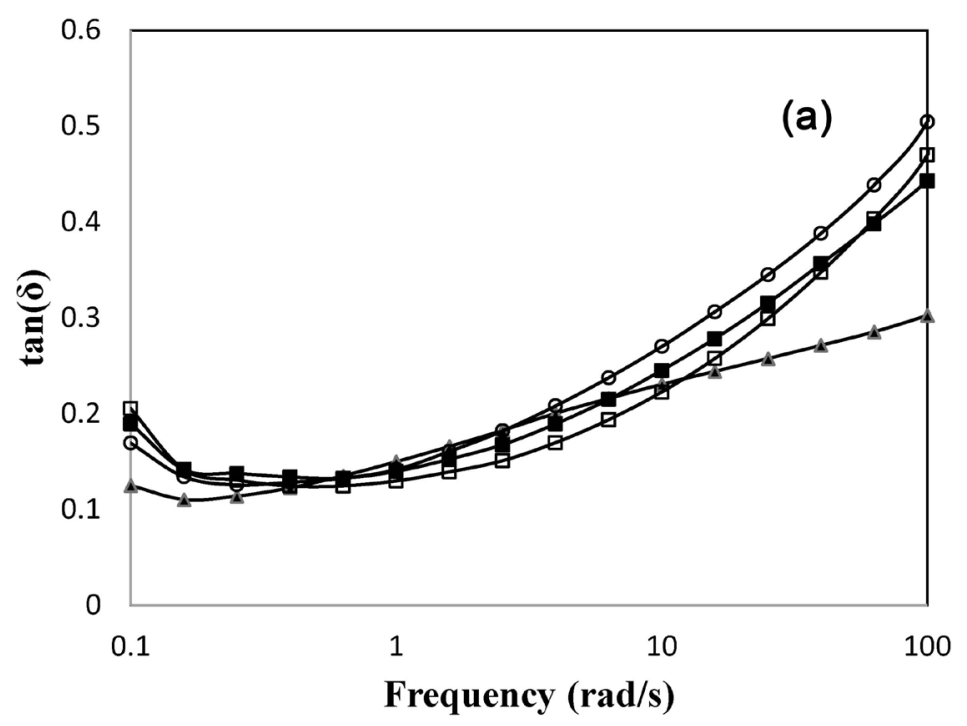

-1-Wheat $\mathrm{G}^{\prime}$

$\rightarrow$ wheat:soybean $(90: 10)$

$\rightarrow$ wheat:soybean (80:20)

$\rightarrow$ wheat:soybean $(70: 30)$
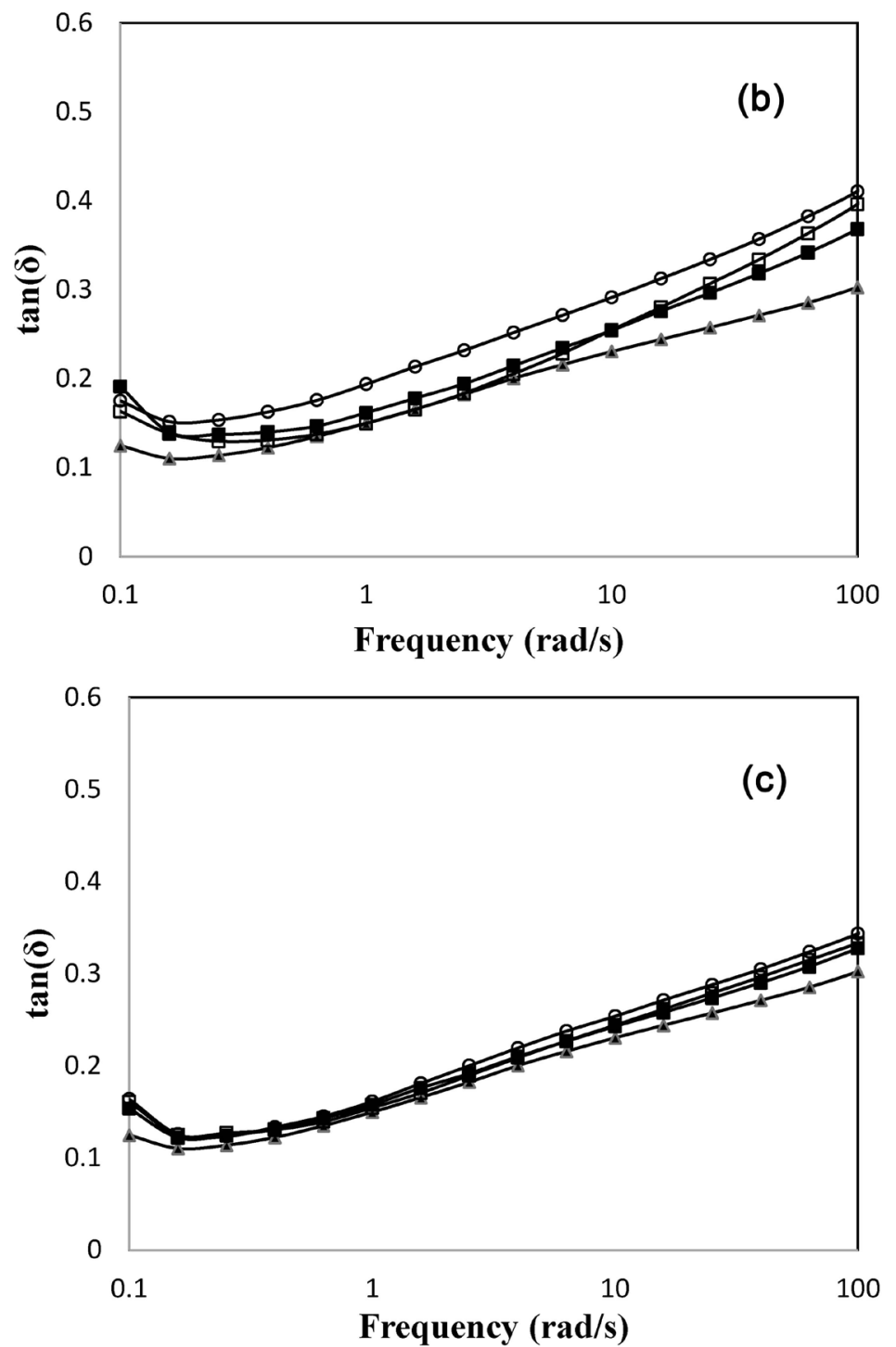

$\rightarrow$ wheat

$\rightarrow$ wheat:navy bean $(90: 10)$

$\rightarrow$ wheat:navy bean $(80: 10)$

- wheat:navy bean $(70: 30)$

Figure 2. Values of $\tan \delta$ versus shear rate for suspensions of wheat and its blends with soybean, lupin and navy bean flours. 
for the 90:10, 80:20, and 70:30 blends of wheat-lupin suspensions were 84.53 $\mathrm{Pa}$, $72.81 \mathrm{~Pa}$ and $57.25 \mathrm{~Pa}$, respectively (Figure $1(\mathrm{~b})$ ). The storage modulus at 1 $\mathrm{rad} / \mathrm{s}$ for the 90:10,80:20, and 70:30 blends of wheat-navy bean suspensions were 116.4 $\mathrm{Pa}, 107.3 \mathrm{~Pa}$ and 102.4 $\mathrm{Pa}$ respectively (Figure $1(\mathrm{c})$ ). The loss tangents for all blend suspensions were similar or somewhat larger than those for wheat suspension, which indicated that soybean, lupin, and navy bean reduced the wheat gluten's elasticity slightly (Figures $2(\mathrm{a})-(\mathrm{c})$ ). It was noticed that the more wheat flour was replaced, the lower values of the elastic moduli were observed. These results implied that even though soybean, lupin, and navy bean possessed higher amount of proteins than wheat, these proteins could not completely and functionally replace gluten. However, soybean, lupin, and navy bean suspensions exhibited pretty strong viscoelasticities even though a little weaker than wheat flour suspension [17]. Therefore, soybean, lupin, and navy bean flours still could be good candidates as gluten-free materials to make new food products with acceptable baking qualities.

The viscosity vs. shear rate for wheat and wheat-soybean blend suspensions, for wheat and wheat-lupin blend suspensions, and for wheat and wheat-navy bean blend suspensions are shown in Figures 3(a)-(c), respectively. Rheological properties of food products, especially shear viscosity, have been used as references for predicting their performance during processing. Most food processing and mastication occur in a shear rate range of 1 to $100 / \mathrm{sec}$ as used in this study [18]. All measured suspensions exhibited shear thinning behaviors over the entire measured shear rates at $25^{\circ} \mathrm{C}$. Shear-thinning behavior of a material is important in industrial operations such as mixing and pumping. In addition, shear-thinning behavior of food products would contribute to a light and non-slimy mouth-feel. The viscosities of all wheat-legume blend suspensions were similar or slightly lower than those of wheat suspension (Figure 3 ). Thus, the processing energy consumption and chewing behaviors of the baking products from wheat-legume blends would be similar to the baking products from wheat alone. Since the experimental conditions were similar to actual processing conditions, all our findings on rheological characteristics could be beneficial for processing and developing new food products.

\subsection{Bread Properties}

The breads made with wheat-legume flours lost a little less water than wheat dough bread during baking (Table 2). This may be attributed to the higher WHCs of the legume flours stated above (Table 1). The moisture of bread crumbs will affect the bread mouthfeel. The moisture content of wheat-navy bean bread crumbs is slightly higher than the other breads. No significant difference was found in the bread crumb moisture content of wheat-soybean and wheat-lupin flour bread compared to wheat flour bread. The crumb $\mathrm{pH}$ represents the sourness of the bread, which is an important character of the bread. Bread containing soybean flour had slightly higher $\mathrm{pH}(6.25-6.46)$ than 

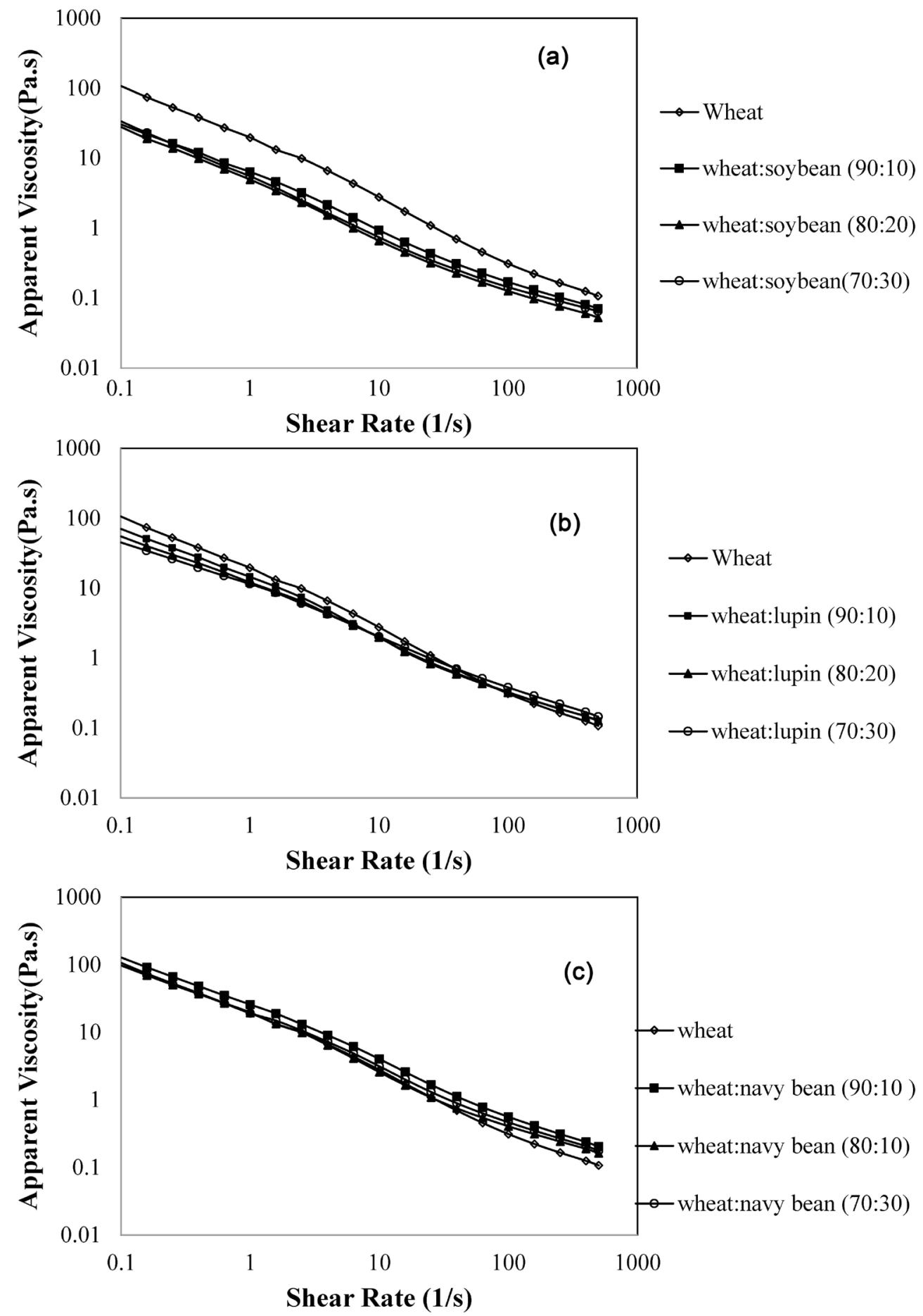

Figure 3. Apparent viscosity versus shear rate for suspensions of wheat and its blends with soybean, lupin and navy bean flours.

wheat flour bread $\mathrm{pH}$ (6.05), and $\mathrm{pH}$ was higher with the increased proportion of soybean flour in bread. It may be mainly attributed to the protein structure changes during yeast fermentation. The $\mathrm{pH}$ of breads containing lupin and navy bean flour was slightly lower than wheat flour bread. Overall, no dramatic difference was observed in bread sourness among all tested breads. 
Compared to the wheat bread, the volumes of 90:10 wheat-soybean, wheat-lupin, and wheat-navy bean breads decreased about $7 \%, 2 \%$, and $10 \%$, respectively (Table 3). Higher substitution levels may result in a further higher reduction in volume for all legume containing breads. The volume reduction as a result of legume substitution appears to be navy bean flour $>$ soybean flour $>$ lupine flour. Although wheat-lupin bread (90:10) volume was $2 \%$ lower compared to wheat flour bread volume, no significant statistical difference was found between 90:10 wheat-lupin bread and wheat flour bread (Table 3).

The bread doughs hardiness with substituted lupin flour was slightly higher $(\sim 123$ to $149 \mathrm{~g})$ than the wheat flour dough ( 118 g) (Table 4). On the other hand, the bread dough hardiness for doughs substituted with navy bean flour

Table 2. Water loss during baking, crumb moisture and $\mathrm{pH}$.

\begin{tabular}{cccc}
\hline Products & Water loss during baking (\%) & Crumb moisture (\%) & Crumb pH \\
\hline $100 \%$ wheat & $10.82 \pm 0.32^{\mathrm{a}}$ & $35.36 \pm 0.06^{\mathrm{cd}}$ & $6.05^{\mathrm{d}}$ \\
$10 \%$ soybean & $10.16 \pm 0.50^{\mathrm{a}}$ & $34.46 \pm 0.41^{\mathrm{cde}}$ & $6.25^{\mathrm{c}}$ \\
$20 \%$ soybean & $8.35 \pm 0.80^{\mathrm{bc}}$ & $32.85 \pm 1.05^{\mathrm{e}}$ & $6.39^{\mathrm{b}}$ \\
$30 \%$ soybean & $8.16 \pm 0.63^{\mathrm{bc}}$ & $33.98 \pm 0.14^{\mathrm{ed}}$ & $6.46^{\mathrm{a}}$ \\
$10 \%$ lupin & $9.03 \pm 0.44^{\mathrm{b}}$ & $35.73 \pm 1.64^{\mathrm{bcd}}$ & $5.89^{\mathrm{f}}$ \\
$20 \%$ lupin & $7.90 \pm 0.00^{\mathrm{c}}$ & $35.47 \pm 0.68^{\mathrm{cd}}$ & $5.84^{\mathrm{g}}$ \\
$30 \%$ lupin & $7.99 \pm 0.08^{\mathrm{c}}$ & $35.64 \pm 0.18^{\mathrm{bcd}}$ & $5.81^{\mathrm{h}}$ \\
$10 \%$ navy bean & $8.86 \pm 0.16^{\mathrm{bc}}$ & $36.21 \pm 0.21^{\mathrm{bc}}$ & $5.94^{\mathrm{e}}$ \\
$20 \%$ navy bean & $8.49 \pm 0.00^{\mathrm{bc}}$ & $37.29 \pm 1.20^{\mathrm{b}}$ & $5.93^{\mathrm{e}}$ \\
$30 \%$ navy bean & $8.29 \pm 0.23^{\mathrm{bc}}$ & $38.62 \pm 0.07^{\mathrm{a}}$ & $5.82^{\mathrm{h}}$ \\
\hline
\end{tabular}

Means \pm standard deviation; $\mathrm{n}=3$; means followed by the same letter within the same column are not significantly different $(P>0.05)$.

Table 3. The weights, volumes and specific volume of breads.

\begin{tabular}{ccccc}
\hline Product & Bread Weight $(\mathrm{g})$ & Volume $\left(\mathrm{cm}^{3}\right)$ & Volume $(\%)$ & Specific value $(\mathrm{mL} / \mathrm{g})$ \\
\hline $100 \%$ wheat & $157.40 \pm 0.57^{\mathrm{e}}$ & $415.58 \pm 7.32^{\mathrm{a}}$ & $100.00 \pm 1.76^{\mathrm{a}}$ & $2.64 \pm 0.04^{\mathrm{a}}$ \\
$10 \%$ soybean & $152.85 \pm 0.21^{\mathrm{g}}$ & $385.06 \pm 4.75^{\mathrm{bcd}}$ & $92.66 \pm 1.14^{\mathrm{bc}}$ & $2.52 \pm 0.03^{\mathrm{b}}$ \\
$20 \%$ soybean & $153.05 \pm 1.34^{\mathrm{g}}$ & $389.20 \pm 6.55^{\mathrm{b}}$ & $93.65 \pm 1.58^{\mathrm{b}}$ & $2.54 \pm 0.07^{\mathrm{b}}$ \\
$30 \%$ soybean & $154.75 \pm 1.06^{\mathrm{f}}$ & $373.38 \pm 7.86^{\mathrm{cd}}$ & $89.85 \pm 1.89^{\mathrm{cd}}$ & $2.41 \pm 0.07^{\mathrm{c}}$ \\
$10 \%$ lupin & $159.65 \pm 0.78^{\mathrm{d}}$ & $407.08 \pm 4.18^{\mathrm{a}}$ & $97.95 \pm 1.01^{\mathrm{a}}$ & $2.55 \pm 0.01^{\mathrm{b}}$ \\
$20 \%$ lupin & $162.10 \pm 0.00^{\mathrm{c}}$ & $378.27 \pm 0.94^{\mathrm{bcd}}$ & $91.02 \pm 0.23^{\mathrm{bcd}}$ & $2.33 \pm 0.01^{\mathrm{cd}}$ \\
$30 \%$ lupin & $160.10 \pm 0.00^{\mathrm{d}}$ & $385.60 \pm 5.64^{\mathrm{bc}}$ & $92.79 \pm 1.36^{\mathrm{bc}}$ & $2.41 \pm 0.04^{\mathrm{cd}}$ \\
$10 \%$ navy bean & $160.50 \pm 0.28^{\mathrm{d}}$ & $371.42 \pm 7.24^{\mathrm{d}}$ & $89.37 \pm 1.74^{\mathrm{d}}$ & $2.31 \pm 0.04^{\mathrm{d}}$ \\
$20 \%$ navy bean & $165.00 \pm 0.00^{\mathrm{b}}$ & $333.23 \pm 6.72^{\mathrm{e}}$ & $80.18 \pm 1.62^{\mathrm{e}}$ & $2.02 \pm 0.04^{\mathrm{e}}$ \\
$30 \%$ navy bean & $168.10 \pm 0.42^{\mathrm{a}}$ & $299.16 \pm 0.09^{\mathrm{f}}$ & $71.99 \pm 0.02^{\mathrm{f}}$ & $1.78 \pm 0.01^{\mathrm{f}}$ \\
\hline
\end{tabular}

Means \pm standard deviation; $\mathrm{n}=3$; means followed by the same letter within the same column are not significantly different $(P>0.05)$. 
Table 4. The texture properties of dough and breads.

\begin{tabular}{cccc}
\hline Product & Dough Hardness $(\mathrm{g})$ & Bread Resilience $(\%)$ & Bread Firmness $(\mathrm{g})$ \\
\hline $100 \%$ wheat & $118.93 \pm 5.51^{\mathrm{e}}$ & $94.65 \pm 1.40^{\mathrm{ab}}$ & $942.32 \pm 44.51^{\mathrm{e}}$ \\
$10 \%$ soybean & $123.40 \pm 4.67^{\mathrm{e}}$ & $93.66 \pm 0.09^{\mathrm{abc}}$ & $1405.51 \pm 28.71^{\mathrm{d}}$ \\
$20 \%$ soybean & $95.50 \pm 2.75^{\mathrm{f}}$ & $93.77 \pm 0.17^{\mathrm{abc}}$ & $1463.88 \pm 45.54 \mathrm{~d}$ \\
$30 \%$ soybean & $89.30 \pm 3.06^{\mathrm{f}}$ & $95.47 \pm 0.02^{\mathrm{a}}$ & $1822.58 \pm 61.01^{\mathrm{bc}}$ \\
$10 \%$ lupin & $123.23 \pm 3.40^{\mathrm{e}}$ & $92.90 \pm 0.14^{\mathrm{bcd}}$ & $937.29 \pm 57.48^{\mathrm{e}}$ \\
$20 \%$ lupin & $149.40 \pm 1.67^{\mathrm{d}}$ & $91.79 \pm 0.05^{\mathrm{d}}$ & $1337.40 \pm 106.04^{\mathrm{b}}$ \\
$30 \%$ lupin & $149.77 \pm 3.58^{\mathrm{d}}$ & $93.62 \pm 0.30^{\mathrm{abc}}$ & $1710.25 \pm 54.45^{\mathrm{c}}$ \\
$10 \%$ navy bean & $247.83 \pm 3.87^{\mathrm{c}}$ & $94.74 \pm 0.52^{\mathrm{ab}}$ & $1889.26 \pm 56.91^{\mathrm{cb}}$ \\
$20 \%$ navy bean & $436.40 \pm 19.12^{\mathrm{b}}$ & $93.82 \pm 0.63^{\mathrm{abc}}$ & $1924.61 \pm 29.40^{\mathrm{b}}$ \\
$30 \%$ navy bean & $746.53 \pm 12.83^{\mathrm{a}}$ & $92.55 \pm 0.44^{\mathrm{cd}}$ & $2120.54 \pm 19.96^{\mathrm{a}}$ \\
\hline
\end{tabular}

Means \pm standard deviation; $\mathrm{n}=3$; means followed by the same letter within the same column are not significantly different $(P>0.05)$.

was much higher ( $247 \mathrm{~g}$ to $746 \mathrm{~g}$ ) compared to the wheat flour dough ( 118 g), and the greater the amount of navy bean flours, the harder the dough. This may be due to the high WHC of navy bean flour (Table 1). Regardless of high protein content, the bread dough substituted with soybean flour had lower dough hardiness compared to wheat flour dough, and the higher the replacement of soybean flour, the lower the dough hardness. This is probably attributed to the fact that the oil content was higher when the replacement of soybean flour increased.

Resilience is an important character of bread. Breads containing soybean, lupin and navy bean flours exhibited remarkable springiness that was similar to breads made from wheat flour (Table 4). Resilience was probably credited to the joint functions of proteins, fiber, and carbohydrates after baking. However, the bread firmness containing soybean, lupin, and navy bean flours was higher than wheat flour bread firmness. The results stated above showed that the higher soybean flour substitution caused lower dough hardiness due to higher oil content. In contrast, the firmness of all the breads was greater when the amount of substitution increased. The reason would be the interactions of additional fibers, oil, and proteins after heating. Among the three breads with substituted flours, lupin flour breads had the lowest firmness compared to soybean flour and navy bean flour bread. In addition, no significant difference in firmness was observed for lupin flour bread at $10 \%$ lupin flour substitution (937.29 g) compared to wheat flour bread (942.32 g). However, bread texture hardiness is a personal preference. Some people like soft bread, while others like hard bread because of the chewy texture.

\subsection{Color}

The value $\left(\mathrm{L}^{\star}\right)$ means lightness with 100 for white and 0 for black. The brown indexes were calculated as $100-L^{*}$ [19]. The substitution of legumes in the bread formulations imparted differences in crust color and crumb color. As 
Table 5. Color of bread crust and crumb.

\begin{tabular}{|c|c|c|c|c|c|c|c|c|}
\hline \multirow{2}{*}{ Products } & \multirow{2}{*}{$L^{*}$} & \multicolumn{2}{|c|}{ Crust Color } & \multirow{2}{*}{ Brown index } & \multirow{2}{*}{$L^{*}$} & \multicolumn{2}{|c|}{ Crumb Color } & \multirow{2}{*}{ Brown index } \\
\hline & & $a^{*}$ & $b^{*}$ & & & $a^{*}$ & $b^{*}$ & \\
\hline $100 \%$ wheat & $49.75^{\mathrm{b}}$ & $16.14^{\mathrm{de}}$ & $29.63^{\mathrm{d}}$ & $50.25^{c}$ & $75.39^{\mathrm{b}}$ & $1.6^{\mathrm{ef}}$ & $20.62^{\mathrm{f}}$ & $24.61^{\mathrm{b}}$ \\
\hline $10 \%$ soybean & $44.26^{\mathrm{c}}$ & $16.81^{\text {cde }}$ & $26.06^{\mathrm{e}}$ & $55.74^{\mathrm{b}}$ & $76.04^{\mathrm{ab}}$ & $1.48^{\mathrm{ef}}$ & $23.21^{\mathrm{e}}$ & $23.96^{b c}$ \\
\hline $20 \%$ soybean & $41.39^{c}$ & $17.60^{\mathrm{bcd}}$ & $26.43^{\mathrm{e}}$ & $58.61^{\mathrm{b}}$ & $73.72^{c}$ & $1.81^{\mathrm{e}}$ & $26.01^{\mathrm{d}}$ & $26.28^{\mathrm{a}}$ \\
\hline $30 \%$ soybean & $37.06^{\mathrm{d}}$ & $18.12^{\mathrm{abc}}$ & $23.59^{\mathrm{f}}$ & $62.94^{\mathrm{a}}$ & $76.40^{\mathrm{ab}}$ & $1.84^{\mathrm{e}}$ & $28.52^{\mathrm{c}}$ & $23.60^{b c}$ \\
\hline $10 \%$ lupin & $49.92^{\mathrm{b}}$ & $17.27^{\text {bcde }}$ & $34.21^{\mathrm{c}}$ & $50.08^{c}$ & $75.94^{\mathrm{ab}}$ & $1.26^{\mathrm{f}}$ & $29.07^{c}$ & $24.06^{b c}$ \\
\hline $20 \%$ lupin & $50.43^{\mathrm{b}}$ & $19.39^{\mathrm{a}}$ & $36.45^{\mathrm{b}}$ & $49.47^{\mathrm{c}}$ & $75.11^{\mathrm{b}}$ & $2.75^{\mathrm{cd}}$ & $35.48^{\mathrm{b}}$ & $24.89^{\mathrm{b}}$ \\
\hline $30 \%$ lupin & $43.37^{\mathrm{c}}$ & $18.97^{\mathrm{ab}}$ & $29.48^{\mathrm{d}}$ & $56.63^{\mathrm{b}}$ & $75.32^{\mathrm{b}}$ & $3.07^{\mathrm{c}}$ & $38.56^{\mathrm{a}}$ & $24.68^{\mathrm{b}}$ \\
\hline $10 \%$ navy bean & $59.11^{\mathrm{a}}$ & $15.67^{\mathrm{e}}$ & $34.41^{\mathrm{c}}$ & $40.89^{\mathrm{d}}$ & $77.36^{\mathrm{a}}$ & $2.60^{\mathrm{d}}$ & $22.33^{\mathrm{e}}$ & $22.64^{\mathrm{c}}$ \\
\hline $20 \%$ navy bean & $56.38^{\mathrm{a}}$ & $17.17^{\text {cde }}$ & $35.81^{\mathrm{bc}}$ & $43.62^{\mathrm{d}}$ & $76.40^{\mathrm{ab}}$ & $3.66^{\mathrm{b}}$ & $22.84^{\mathrm{e}}$ & $23.60^{\mathrm{bc}}$ \\
\hline $30 \%$ navy bean & $58.39^{\mathrm{a}}$ & $17.80^{\mathrm{abcd}}$ & $40.15^{\mathrm{a}}$ & $41.60^{\mathrm{d}}$ & $73.15^{\mathrm{c}}$ & $4.93^{\mathrm{a}}$ & $23.12^{\mathrm{e}}$ & $26.85^{\mathrm{a}}$ \\
\hline
\end{tabular}

Means followed by the same letter within the same column are not significantly different $(P>0.05)$.

expected, the crust brown indexes (40.60 to 62.94) were considerably higher than that of crumb color (22.64 - 26.85), and larger differences were observed on crust color than crumb color between breads (Table 5). The substitution of legumes in the bread formulations imparts a slightly darker crust color with the exception of breads with the soybean flour substitution. Bread with soybean flour substitution had a slightly higher brown index than wheat flour bread, whereas bread substituted with lupin flour was similar in color to wheat flour bread.

\section{Conclusion}

Bread substituted with legume flour will improve the nutritional value of bakery products. This study found that bread substituted with $10 \%$ lupin flour had similar bread quality properties of volume, texture, and color to those of wheat flour bread. In addition, lupin flour had the advantage of no "off" flavor or smell as soybean flour. Thus, lupin flour appears to be the best substitution candidate among the legumes tested for fortified bread making. Lupin can be presented as a high-value protein source in developing marketable foods for health conscious consumers.

\section{References}

[1] Dalaram, I.S. (2017) Evaluation of Total Polyphenol Content and Antioxidant Capacity of Different Verity Lupin Seeds. Potravinarstvo Slovak Journal of Food Sciences, 11, 26-34.

[2] (2017) USDA National Nutrient Database for Standard Reference. http://ndb.nal.usda.gov/ndb/search/list

[3] Handa, C.L., Couto, U.R., Vicensoti, A.H., Georgetti, S.R. and Ida, E.I. (2014) Optimisation of Soy Flour Fermentation Parameters to Produce $\beta$-Glucosidase for Bioconversion into Aglycones. Food Chemistry, 152, 56-65. 
https://doi.org/10.1016/j.foodchem.2013.11.101

[4] Sacks, F.M., Lichtenstein, A., Van Horn, L., Harris, W., Kris-Etherton, P. and Winston, M. (2006) Soy Protein, Isoflavones, and Cardiovascular Health: An American Heart Association Science Advisory for Professionals from the Nutrition Committee. Circulation, 113, 1034-1044. https://doi.org/10.1161/CIRCULATIONAHA.106.171052

[5] Ha, V., Sievenpiper, J.L., de Souza, R.J., Jayalath, V.H., Mirrahimi, A., Agarwal, A., Chiavaroli, L., Blanco Mejia, S., Sacks, F.M., Di Buono, M., et al. (2014) Effect of Dietary Pulse Intake on Established Therapeutic Lipid Targets for Cardiovascular Risk Reduction: A Systematic Review and Meta-Analysis of Randomized Controlled Trials. Canadian Medical Association, 186, E252-E262.

https://doi.org/10.1503/cmaj.131727

[6] McPherson, R. (1992) Dietary Fiber-A Perspective. In: Spiller, G.A., Ed., Dietary Fiber in Human Nutrition, 2nd Edition, CRC Handbook, CRC Press, Boca Raton, 7-11.

[7] Liu, S. X., Singh, M., Wayman, A. E., Chen, D., and Kenar, J. A. (2017) Evaluation of Soybean-Navy Bean Emulsions Using Different Processing Technologies. Beverages, 3, 23.

[8] CGIAR (2017) Improving Nutrition and Health. http://grainlegumes.cgiar.org/why-grain-legumes-matter/improving-nutrition-andhealth/

[9] AACC (1998) Straight-Dough Bread-Baking Method-Long Fermentation. AACC Method (10-09). American Association of Cereal Chemists, St. Paul.

[10] Ade-Omowaye, B.I.O., Taiwo, K.A., Eshtiaghi, N.M., Angersbach, A. and Knorr, D. (2003) Comparative Evaluation of the Effects of Pulsed Electric Field and Freezing on Cell Membrane Permeabilisation and Mass Transfer during Dehydration of Red Bell Peppers. Innovative Food Science and Emerging Technologies, 4, 177-188. https://doi.org/10.1016/S1466-8564(03)00020-1

[11] AACC (1998) AACC Method (10-05. 01): Guidelines for Measurement of Volume by Rapeseed Displacement. American Association of Cereal Chemists, St. Paul.

[12] Yu, Y., Wang, L., Qian, H., Zhang, H. and Qi, X. (2018) Contribution of Spontaneously-Fermented Sourdoughs with Pear and Navel Orange for the Bread-Making. $L W T, 89,336-343$. https://doi.org/10.1016/j.lwt.2017.11.001

[13] Ferry, J.D. (1980) Viscoelastic Properties of Polymers. 3rd Edition, John Wiley, New York.

[14] SAS Institute Inc. (1999) The SAS ${ }^{\circledR}$ System for Windows ${ }^{\circledR}$, Version 8e. Cary.

[15] Traynham, T.L., Myers, D.J., Carriquiry, A.L. and Johnson, L.A. (2007) Evaluation of Water-Holding Capacity for Wheat-Soy Flour Blends. Journal of the American Oil Chemists' Society, 84, 151-155. https://doi.org/10.1007/s11746-006-1018-0

[16] Qiu, S., Yadav, M.P. and Yin, L. (2017) Characterization and Functionalities Study of Hemicellulose and Cellulose Components Isolated from Sorghum Bran, Bagasse and Biomass. Food Chemistry, 230, 225-233. https://doi.org/10.1016/j.foodchem.2017.03.028

[17] Xu, J., Mohamed, A.A. and Sessa, J.D. (2008) Rheological Properties of Lupin Protein Suspensions. International Journal of Agricultural Research, 3, 317-324. https://doi.org/10.3923/ijar.2008.317.324

[18] Bloksma, A. (1988) Rheology of the Bread Making Process. 8 th International Cereal and Bread Congress, Lausanne. 
[19] Giannone, V., Giarnetti, M., Spina, A., Todaro, A., Pecorino, B., Summo, C., Caponio, F., Paradiso, V.M. and Pasqualone, A. (2018) Physico-Chemical Properties and Sensory Profile of Durum Wheat Dittaino PDO (Protected Designation of Origin) Bread and Quality of Re-Milled Semolina Used for Its Production. Food Chemistry, 241,242-249. https://doi.org/10.1016/j.foodchem.2017.08.096 